\title{
Pengembangan Mobile Learning Berbasis Android pada Materi Listrik Dinamis
}

\author{
Nining Gagese, Unggul Wahyono dan Yusuf Kendek \\ nining_gagese86@yahoo.co.id \\ Program Studi Pendidikan Fisika FKIP Universitas Tadulako \\ Jl. Soekarno Hatta Km. 9 Kampus Bumi Tadulako Tondo Palu - Sulawesi Tengah
}

\begin{abstract}
ABSTRAK: Penelitian ini dilakukan untuk menghasilkan mobile learning dalam bentuk aplikasi berbasis android pada materi listrik dinamis. Adapun tujuan dari penelitian ini adalah untuk mengetahui kelayakan aplikasi android. Penelitian ini merupakan penelitian pengembangan dan mengacu pada model pengembangan ADDIE yang meliputi tahap analisis, tahap desain, tahap pengembangan, tahap implementasi dan tahap evaluasi. Subjek penelitian uji coba kelayakan aplikasi android dilakukan pada siswa kelas IX yang berjumlah 20 orang. Hasil uji coba dan analisis angket menunjukkan bahwa rata-rata skor penilaian ahli materi sebesar 3,48 dan dikategorikan "Sangat Baik", rata-rata skor ahli media sebesar 3,48 dan dikategorikan "Sangat Baik", analisis kelayakan oleh guru dengan skor rata-rata sebesar 3,65 dan dikategorikan "Sangat Baik" dan hasil analisis penilaian respon siswa diperoleh skor rata-rata sebesar 3,10 dan dikategorikan "Setuju". Hasil penelitian menunjukkan bahwa program mobile learning berbasis android yang dikembangkan dapat dijadikan sebagai media pembelajaran bagi siswa.
\end{abstract}

Kata Kunci: Mobile Learning, Android, Listrik Dinamis

\section{PENDAHULUAN}

Fisika merupakan salah satu ilmu sains yang mempelajari tentang konsep-konsep, hukumhukum, rumus-rumus, dan juga gejala-gejala yang bersifat nyata maupun abstrak. Untuk mengerti fisika itu sendiri tidak cukup dengan hanya menghafal materi dan rumus tetapi juga harus memahami konsep-konsep yang dikandungnya. Hal ini menyebabkan fisika masih dianggap sulit oleh siswa sehingga timbul rasa bosan untuk mempelajarinya.

Siswa merasa fisika merupakan pelajaran sulit serta penuh dengan rumus-rumus, banyaknya materi pelajaran yang harus dihafalkan, kurangnya motivasi dari dalam diri siswa untuk mempelajari fisika, serta ketidaktepatan model, metode, dan media pembelajaran yang digunakan oleh guru, sehingga kegiatan pembelajaran terasa jenuh dan membosankan. ${ }^{[1]}$ Masalah ini dapat diatasi dengan memperhatikan salah satu komponen dalam sistem pembelajaran, yaitu media pembelajaran yang digunakan. Media pembelajaran memiliki peranan penting dalam mendukung kelancaran proses belajarmengajar. Agar pembelajaran fisika lebih menarik diperlukan media pembelajaran yang lebih baik dan menarik sehingga diharapkan bisa membuat siswa lebih tertarik pada materi pelajaran yang disampaikan oleh guru. ${ }^{[2]}$

Pengembangan media pembelajaran dapat meningkatkan kreativitas guru dalam menciptakan suasana belajar yang efektif dan menyenangkan. Selain itu juga dapat menghindari kejenuhan pada siswa dalam proses belajar mengajar. Menurut Wina Sanjaya (2012), ada tiga tahapan pengembangan media, yaitu tahapan perencanaan, tahapan pengembangan naskah dan tahap produksi media. ${ }^{[3]}$ Salah satu bentuk dari pengembangan media pembelajaran yaitu melalui Teknologi, Informasi dan Komunikasi, misalnya e-learning. Salah satu bentuk dari e-learning yaitu mobile learning.

Mobile learning memiliki kelebihan yang dapat memudahkan penggunanya. Menurut Aprianti (2011), melalui mobile learning siswa dapat mengakses materi sekolah, tugas dan informasi sekolah dimanapun dan kapanpun, memiliki harga yang lebih murah dibandingkan dengan PC Desktop, ukuran perangkat yang lebih kecil dan ringan daripada PC Desktop, serta diperkirakan dapat mengikutsertakan lebih banyak pelajar karena mobile learning memanfaatkan teknologi yang biasa digunakan dalam kehidupan sehari-hari. ${ }^{[4]}$

Mobile learning dapat diaplikasikan pada smartphone dengan sistem operasi android. Android merupakan platform yang bersifat open source (terbuka) sehingga tidak merujuk pada suatu perusahaan hardware atau provider. Platform terbuka memungkinkan para pengembang bebas untuk mengembangkan aplikasinya sendiri. Perangkat lunak open source bisa menjadi alternatif untuk mengembangkan media pembelajaran yang murah dan handal. Mengingat juga rata-rata kualitas perangkat lunak open source tidak kalah dengan perangkat lunak berbayar. Hal ini dikarenakan dukungan sukarelawan pengembang perangkat lunak open source di berbagai negara. ${ }^{[5]}$ 
Smartphone dengan sistem operasi android tentunya sudah banyak digunakan di kalangan masyarakat Indonesia. Indonesia berada di peringkat kelima daftar pengguna smartphone terbesar di dunia dimana populasi android telah mencapai lebih dari 1 miliar. ${ }^{[6]}$ Menurut Setyaningsih dan Nuryati (2016), hampir 51\% smartphone android mampu menguasai pangsa pasar kebutuhan mobile di Indonesia. ${ }^{[7]}$ Menurut hasil survei Opera yang dikutip dalam Fatimah \& Mufti (2014), diperoleh bahwa $10 \%$ pengguna android adalah umur 13-17 tahun, hal ini menunjukkan bahwa anak dengan usia tingkat SMP sampai SMA memiliki perhatian yang cukup besar dalam penggunaan smartphone. ${ }^{[8]}$

\section{METODE PENELITIAN}

Penelitian ini termasuk jenis penelitian dan pengembangan atau dikenal Research and Developement (R\&D) yaitu model penelitian yang digunakan untuk menghasilkan produk tertentu, dan menguji keefektifan produk tersebut. ${ }^{[9]}$ Penelitian pengembangan mobile learning berbasis android pada materi listrik dinamis, diadaptasi dari langkah-langkah model penelitian pengembangan ADDIE. Langkahlangkah penelitian secara umum adalah seperti yang ditunjukan pada Gambar 1.

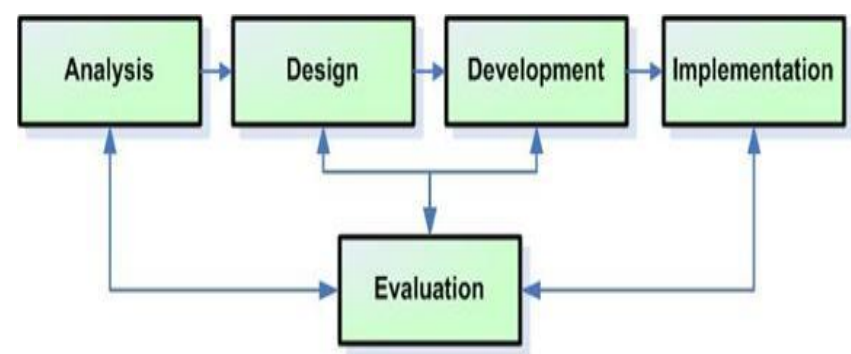

Gbr 1. Desain Penelitian Pengembangan Model ADDIE

1. Tahap Analisis

Tahap analisis meliputi dua cara, yaitu melalui studi literatur dan studi lapangan. Studi literatur dilakukan dengan mencari informasi dan referensi dari buku, jurnal dan browsing internet.

2. Tahap Desain

Desain awal yang dihasilkan meliputi tampilan awal atau home, tampilan menu materi dan tampilan dasar materi yang terbagi menjadi 3 bagian, yaitu materi, contoh soal dan tokoh.

3. Tahap Pengembangan

Tahap ini terbagi dalam 3 kegiatan, yaitu:pembuatan aplikasi, validasi/uji kelayakan aplikasi dan revisi aplikasi.

a. Pembuatan aplikasi

Aplikasi ini dibuat dengan menggunakan Android Studio yang merupakan IDE resmi dari Google khusus untuk para developer android.

1) Splashscreen
Merupakan tampilan sekilas sebelum home ketika aplikasi pertama kali dibuka yang bisa diatur waktu atau durasi tampilannya. Durasi tampilan splashscreen ini diatur selama 5 detik.

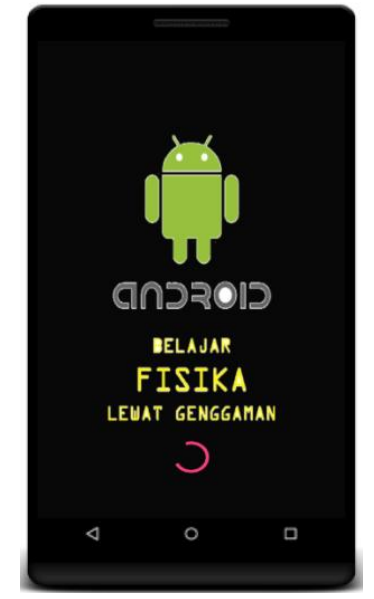

Gbr 2. Tampilan Splashscreen

\section{2) Home}

Tampilan awal atau home muncul secara otomatis setelah splashscreen. Home terdiri dari 5 menu, yaitu menu materi, latihan, about app dan profil.

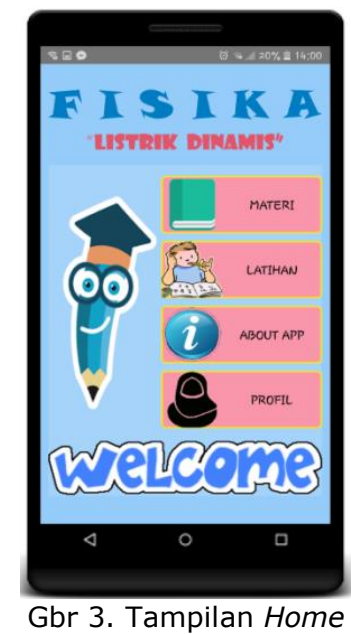

3) Menu Materi

Menu materi terdiri dari sub menu tujuan pembelajaran, pengantar materi, arus listrik, beda potensial, hukum Ohm, rangkaian listrik dan hukum 1 Kirchoff.

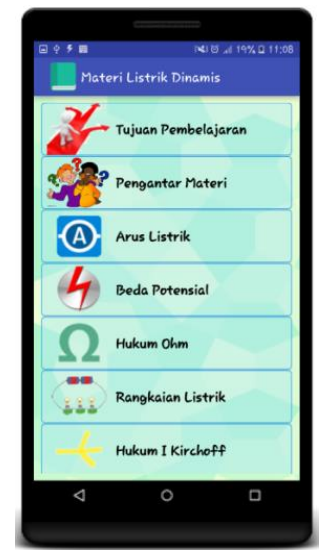

Gbr 4. Tampilan Menu Materi 
4) Materi Listrik Dinamis

Tampilan berbentuk tab layout yang terdiri dari tiga tab yaitu tab materi, contoh soal dan tokoh. Gambarnya terbagi dua, yaitu gambar diam dan gambar bergerak berformat gif.

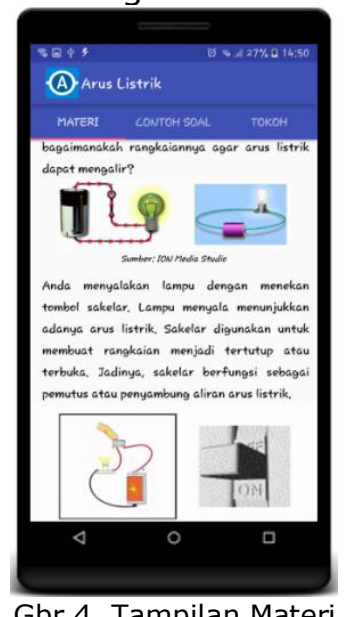

b. Validasi/uji kelayakan aplikasi

Sebelum diujicobakan, aplikasi divalidasi terlebih dahulu dengan maksud agar aplikasi yang telah dikembangkan dapat diketahui kelemahan dan kekurangannya. Validasi ini dilakukan oleh validator ahli materi dan ahli media dengan cara mengisi lembar angket penilaian.

\section{Revisi Aplikasi}

Revisi aplikasi dilakukan setelah aplikasi dinilai oleh ahli. Aplikasi diperbaiki berdasarkan saransaran dari ahli materi dan ahli media.

4. Tahap Implementasi

Pada tahap ini telah dilakukan uji coba pada guru mata pelajaran dan 20 siswa di dua tempat atau lokasi penelitian, yaitu 14 siswa di SMP Lab School UNTAD Palu dan 6 siswa di Lembaga Pendidikan Primagama Cabang Palu.

\section{Tahap Evaluasi}

Evaluasi yaitu proses untuk melihat apakah produk yang telah dikembangkan berhasil atau tidak. Sebenarnya tahap evaluasi bisa terjadi pada setiap empat tahap tersebut di atas. Evaluasi ini dinamakan evaluasi formatif, karena tujuannya untuk kebutuhan revisi.

Instrumen yang digunakan pada penelitian ini adalah berupa angket yang diberikan kepada ahli media, ahli materi, guru mata pelajaran dan siswa sebagai respondennya. Data yang diperoleh melalui instrumen penilaian pada saat uji coba dianalisis dengan menggunakan statistik deskriptif kualitatif yang memaparkan hasil pengembangan mobile learning tersebut. Analisis ini dimaksud untuk menggambarkan karakteristik data pada masing-masing variabel. Dengan cara ini diharapkan dapat mempermudah memahami data untuk proses selanjutnya. Hasil analisis data digunakan sebagai dasar untuk merevisi produk media yang dikembangkan.

Teknik analisis yang digunakan untuk menganalisis data hasil validasi adalah perhitungan nilai rata-rata. Penentuan teknik ini berdasarkan pendapat dari Arikunto yang menyatakan bahwa untuk mengetahui peringkat nilai akhir pada setiap butir angket penelitian, jumlah nilai yang diperoleh dibagi dengan banyaknya responden yang menjawab angket penilaian tersebut. ${ }^{[10]}$ Jadi diperoleh rumus untuk menghitung nilai rata-rata adalah:

$$
\bar{X}=\frac{\sum x}{n}
$$

Keterangan :

$\overline{\mathrm{X}}$ : nilai rata-rata dalam tiap butir pertanyaan

$\sum x$ : jumlah nilai dari seluruh penilaian dalam tiap butir pertanyaan

$n$ : jumlah butir pernyataan

Cara mengubah skor rata-rata yang diperoleh melalui angket ke dalam bentuk kualitatif berdasarkan Tabel 1. ${ }^{[11]}$

TABEL 1. Kategori Skala Likert

\begin{tabular}{cc}
\hline Interval Skor & Kriteria \\
\hline $3,25<\bar{X} \leqslant 4,00$ & Sangat baik (SB) \\
$2,50<\bar{X} \leqslant 3,25$ & Baik (B) \\
$1,75<\bar{X} \leqslant 2,50$ & Kurang (K) \\
$1,00 \leqslant \bar{X} \leqslant 1,75$ & Sangat Kurang (SK) \\
\hline
\end{tabular}

Analisis data respon siswa serupa dengan analisis kualitas penilaian produk. Rata-rata skor dari angket respon selanjutnya diubah ke dalam bentuk kualitatif berdasarkan Tabel 2 .

TABEL 2. Kriteria Kategori Respon Siswa

\begin{tabular}{cc}
\hline Skor Rata-rata & Kategori \\
\hline $3,25<\bar{X} \leqslant 4,00$ & Sangat Setuju (SS) \\
$2,50<\bar{X} \leqslant 3,25$ & Setuju (S) \\
$1,75<\bar{X} \leqslant 2,50$ & Kurang Setuju (KS) \\
$1,00 \leqslant \bar{X} \leqslant 1,75$ & Tidak Setuju (TS) \\
\hline
\end{tabular}

Tabel 2 di atas merupakan acuan penilaian data yang dihasilkan dari validasi ahli materi, ahli media, guru mata pelajaran dan uji coba pada siswa agar mempermudah dalam pemberian suatu kriteria nilai bahwa mobile learning yang dikembangkan sudah layak atau belum untuk digunakan sebagai media pembelajaran.

\section{HASIL DAN PEMBAHASAN}

\section{A. Hasil Penelitian}

1. Validasi oleh Ahli Materi

Aspek yang dinilai oleh ahli materi meliputi aspek kurikulum, penyajian materi dan kebahasaan. Hasil penilaian oleh ahli materi disajikan dalam diagram Gambar 5 berikut. 


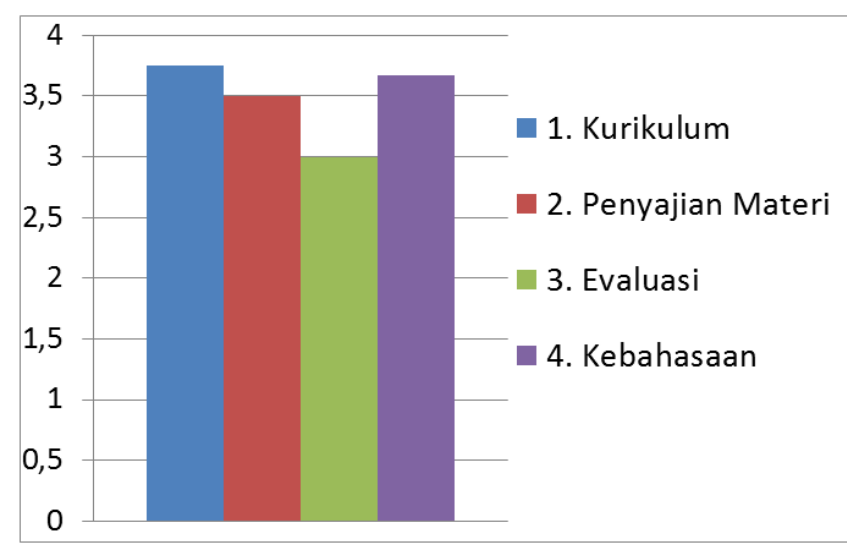

Gbr 5. Diagram Penilaian Ahli Materi

Adapun saran dan kritik oleh ahli materi adalah:

1) Tidak semua soal evaluasi mengcover tujuan pembelajaran

2) Aplikasi terkadang mengalami error

3) Penempatan suatu objek menutupi objek yang lainnya

2. Validasi oleh Ahli Media

Aspek yang diniliai oleh ahli media meliputi aspek kualitas tampilan, desain tampilan dan keterlaksanaan. Hasil penilaian oleh ahli media disajikan dalam diagram Gambar 6 berikut.

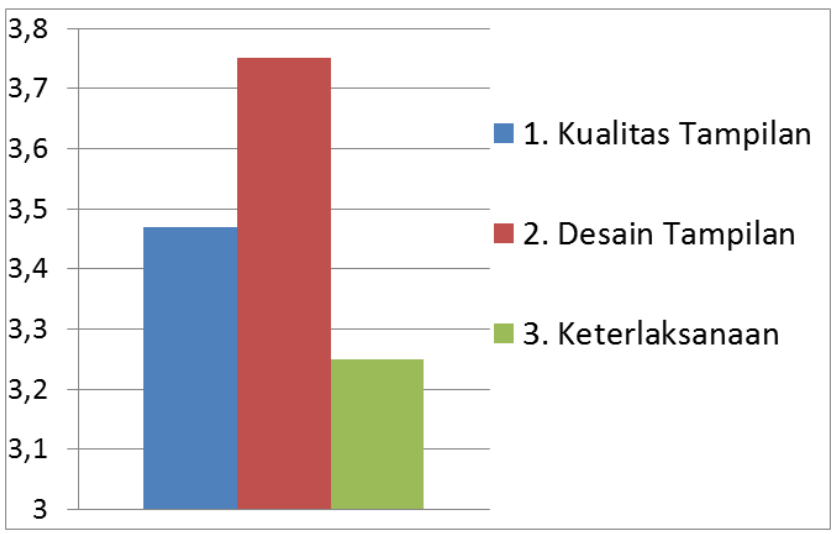

Gbr 6. Diagram Penilaian Ahli Media

Adapun saran dan kritik oleh ahli media adalah:

1) Tambahkan pada latihan sesi pertanyaan konsep

2) Tambahkan gambar yang berkaitan dengan kehidupan sehari-hari

3) Tuliskan sumber gambar

3. Penilaian Kelayakan Oleh Guru

Aspek yang dinilai dalam kelayakan penggunaan aplikasi ini adalah aspek kurikulum, penyajian materi, evaluasi, kebahasaan, kualitas tampilan, desain tampilan dan keterlaksanaan. Hasil penilaian oleh guru disajikan dalam diagram Gambar 7 berikut.

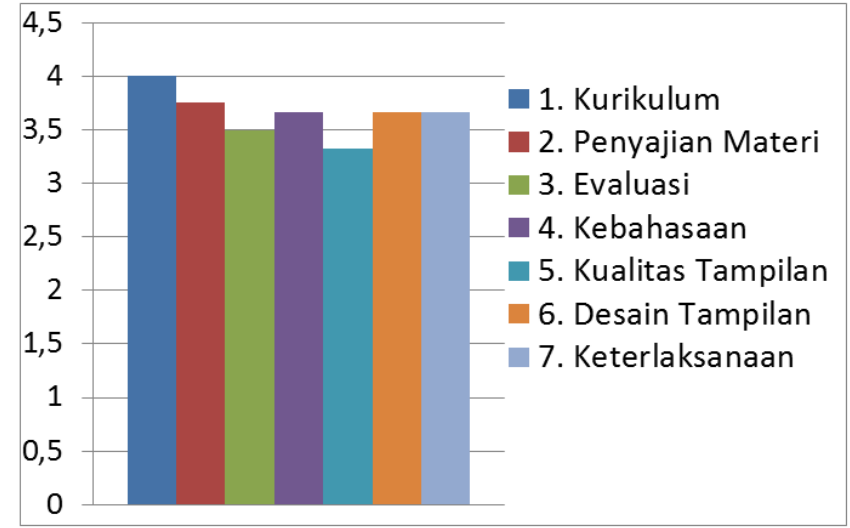

Gbr 7. Diagram Penilaian Guru

Adapun saran dan kritik oleh guru mata pelajaran adalah:

1) Gambar pada menu home masih perlu perbaikan karena kualitas gambarnya masih kurang

2) Videonya kurang, sebaiknya ditambah lagi

4. Hasil Penilaian Respon Siswa

Uji coba dilakukan terhadap 20 siswa melalui pengisian angket yang memiliki 10 item pernyataan bersifat positif dengan empat opsi atau pilihan, yaitu sebagai berikut: 4: Sangat setuju; 3: Setuju; 2: Kurang setuju; 1: Tidak setuju. Hasil penilaian oleh siswa disajikan dalam Tabel 3 berikut.

TABEL 3. Hasil Penilaian Respon Siswa

\begin{tabular}{cc}
\hline No. Item & Skor Rata-rata \\
\hline 1 & 3,30 \\
2 & 2,95 \\
3 & 2,80 \\
4 & 2,45 \\
5 & 2,95 \\
6 & 3,25 \\
7 & 3,15 \\
8 & 3,25 \\
9 & 3,45 \\
10 & 3,40 \\
\hline Total Rata-rata & 3,10 \\
\hline
\end{tabular}

\section{B. Pembahasan}

Penelitian pengembangan mobile learning berbasis android pada materi listrik dinamis untuk siswa SMP Kelas IX ini bertujuan untuk mengetahui kelayakannya seagai media pembelajaran fisika. Selain itu, juga dapat memberikan manfaat bagi siswa dalam memahami konsep fisika, memperbaiki kualitas pembelajaran melalui media yang inovatif serta dapat digunakan sebagai acuan atau bahan informasi untuk pengembangan berikutnya di materi lain.

Aplikasi android ini dapat beroperasi pada smartphone dengan spesifikasi OS android 4.1 Jelly Bean (API level 16) untuk Minimum SDK Version dan android 6.0 Marshmallow (API level 23) untuk Target SDK Version. Aplikasi ini 
mendukung smartphone dengan resolusi layar $480 \times 800,540 \times 960,720 \times 1280$ dan $1080 \times$ 1920. Selain itu, aplikasi ini memerlukan 33,32 MB dari memori perangkat saat penginstalan dan RAM sebesar 82 MB saat dioperasikan.

Analisis data hasil pengembangan mobile learning ini didasarkan pada hasil validasi dan uji coba. Desain uji coba yang digunakan dalam penelitian ini adalah uji kelayakan terhadap aplikasi. Uji coba dilakukan oleh satu dosen fisika sebagai validator ahli materi, satu dosen fisika sebagai validator ahli media, satu guru fisika yang menganalisis kelayakan penggunaan aplikasi mobile learning serta 20 siswa SMP Kelas IX.

Validator ahli materi dilakukan oleh dosen Fisika FKIP UNTAD. Aspek yang dinilai dari aplikasi mobile learning ini meliputi aspek kurikulum, penyajian materi, evaluasi dan kebahasaan. Rata-rata hasil penilaian dari aspek kurikulum adalah 3,75 , aspek penyajian materi adalah 3,50, aspek evaluasi adalah 3,00 dan aspek kebahasaan adalah 3,67. Skor rata-rata keseluruhan dari ahli materi yaitu 3,48 dan dikategorikan "Sangat Baik". Dari hasil tersebut ahli materi menyatakan bahwa aplikasi mobile learning ini layak untuk di uji cobakan di lapangan dengan revisi sesuai saran.

Validator ahli media dilakukan oleh dosen Fisika FKIP UNTAD. Aspek yang dinilai dari aplikasi mobile learning ini meliputi aspek kualitas tampilan, desain tampilan dan keterlaksanaan. Rata-rata hasil penilaian dari aspek kualitas tampilan adalah 3,43, aspek desain tampilan adalah 3,75 dan aspek keterlaksanaan adalah 3,25. Skor rata-rata keseluruhan dari ahli media yaitu 3,48 dan dikategorikan "Sangat Baik". Dari hasil tersebut ahli media menyatakan bahwa aplikasi mobile learning ini layak untuk di uji cobakan di lapangan dengan revisi sesuai saran.

Aspek yang dinilai dalam uji kelayakan penggunaan oleh guru mata pelajaran adalah aspek kurikulum, penyajian materi, evaluasi, kebahasaan, kualitas tampilan, desain tampilan dan keterlaksanaan. Skor rata-rata hasil penilaian dari aspek kurikulum adalah 4,00, aspek penyajian materi adalah 3,75, aspek evaluasi adalah 3,50 , aspek kebahasaan adalah 3,67, aspek kualitas tampilan adalah 3,33, aspek desain tampilan adalah 3,67 dan aspek keterlaksanaan adalah 3,67. Skor rata-rata keseluruhan dari uji kelayakan oleh guru adalah 3,65 dan dikategorikan "Sangat Baik".

Hasil pengembangan mobile learning diujikan lagi kepada 20 siswa yang berada di dua tempat berbeda, yaitu 14 siswa dari SMP Lab School UNTAD Palu dan 6 siswa dari SMPN Model Terpadu Madani Palu yang mengambil kelas privat di Lembaga Pendidikan Primagama Cabang Palu. Berdasarkan Tabel 2, skor 3,10 tersebut termasuk dalam kategori "Setuju" sehingga dapat dikatakan bahwa aplikasi android yang dikembangkan ini layak digunakan sebagai media pembelajaran fisika.

Tentunya aplikasi ini memiliki kelebihan dan kekurangan. Kelebihan dari aplikasi ini antara lain mudah dalam pengoperasiannya, memiliki ukuran yang tidak terlalu besar, terdapat konten video dan gambar bergerak yang dapat mendukung atau menguatkan konsep yang disajikan, penggunaan kalimat yang singkat, padat, jelas dan komunikatif, serta dapat digunakan dimana saja dan kapan saja karena bersifat offline atau tidak memerlukan koneksi internet.

Kekurangan dari aplikasi ini yaitu belum digunakan atau diterapkannya fungsi math dalam proses memasukkan formula atau rumus fisika. Sebelum dimasukkan dalam pemrogramannya, rumus yang masih berbentuk file gambar diubah bentuknya menjadi gambar vektor untuk mengakali tampilannya agar tidak terkesan seperti file gambar sehingga membutuhkan tambahan waktu hanya untuk menampilkan rumus-rumus fisikanya. Selain itu, Berdasarkan hasil uji coba yang telah dilakukan ditemukan bahwa aplikasi ini mengalami error pada tampilan tab layout di tipe android tertentu yang telah ditargetkan.

\section{KESIMPULAN}

Berdasarkan analisis data dan pembahasan, maka penelitian ini dapat disimpulkan bahwa:

1) Telah dikembangkan mobile learning dalam bentuk aplikasi android pada materi listrik dinamis.

2) Hasil penilaian yang diberikan oleh ahli materi, ahli media, guru mata pelajaran dan 20 orang siswa SMP Kelas IX terhadap kelayakan aplikasi menunjukkan bahwa aplikasi android tersebut memenuhi kriteria baik dan layak digunakan sebagai media pembelajaran fisika.

\section{DAFTAR PUSTAKA}

1] Astra I.M, dkk. 2012. Aplikasi Mobile Learning Fisika dengan Menggunakan Adobe Flash sebagai Media Pembelajaran Pendukung. Jurnal Pendidikan dan Kebudayaan. Vol 18, No 2, Juni 2012.

2] Utami. 2014. Efektivitas Pemanfaatan Media Pembelajaran Animasi Untuk Meningkatkan Motivasi dan Hasil Belajar Fisika Siswa Madrasah Aliyah Negeri Wonosobo. Prosiding Pertemuan Ilmiah XXVIII HFI Jateng \& DIY, (334-337). Yogyakarta, 26 April 2014.

3] Sanjaya, W. 2012. Media Komunikasi Pembelajaran. Jakarta : Kencana Prenada Media Group.

4] Aprianti, L. 2011. Implementasi Mobile Learning sebagai Media Bantu pembelajaran untuk Mendukung Ujian 
Nasional Tingkat SMP Berbasis Android di SMP $N 1$ Klaten. Skripsi S1 pada STTA Yogyakarta: tidak diterbitkan.

5] Hendratmoko, T. 2015. Software Open Source Untuk Mengembangkan Media Pembelajaran. Seminar Nasional Teknologi Pendidikan UM, 2015.

6] Gifary, S \& Iis K.N. 2015. Intensitas Penggunaan Smartphone Terhadap Perilaku Komunikasi. Jurnal Sosioteknologi. Vol 14, No 2, Agustus 2015.

7] Setyaningsih P \& Nuryati. 2016. Kepuasan Konsumen Pengguna Smartphone Android Samsung Melalui Kualitas Produk, Merek dan Harga di Kecamatan Grogol
Kabupaten Sukoharjo. ADVANCE. Vol 3, No 1, Maret 2016. ISSN: 2337-5221

8] Fatimah, S \& Yusuf Mufti. (2014). Pengembangan Media Pembelajaran IPA-Fisika Smartphone Berbasis Android Sebagai Penguat Karakter Sains Siswa. J. Kaunia. Vol X, No 1, April 2014. ISSN: 1829-5266.

[9] Sugiyono. (2009). Metode Penelitian Kuantitatif, Kualitatif dan $R \& D$, Bandung: Alfabeta

10] Arikunto, S. (2006). Prosedur Penelitian: Suatu Pendekatan Praktik. Jakarta: Rineka Cipta

11] Widoyoko. (2012). Teknik Penyusunan Instrumens Penelitian. Yogyakarta: Pustaka Pelajar 